\title{
Comparison between the Fractions and Extractants of Phosphorus of PAJANCOA and RI Farm using Different Statistical Analysis
}

\author{
Ashna Susan Joseph ${ }^{1}{ }^{*}$, A. Baskar ${ }^{1}$, U. Bagavathi Ammal ${ }^{1}$ and V. Chellamuthu ${ }^{2}$ \\ ${ }^{1}$ Department of Soil Science \&Agricultural Chemistry, University of Agricultural Sciences, \\ Raichur, Karnataka, India \\ ${ }^{2}$ Department of Agronomy, Pandit Jawaharlal Nehru College of Agriculture and Research \\ Institute, Karaikal, India \\ *Corresponding author
}

\section{A B S T R A C T}

\section{Keywords}

Fractions of $\mathrm{P}$, extractants of $P$, Olsen-P, Bray I-P, Bray II-P, NaCl-P, $\mathrm{NaOH}-\mathrm{P}, \mathrm{HCl}-\mathrm{P}$, Triacid-P

\section{Article Info}

Accepted:

20 August 2020

Available Online:

10 September 2020

\begin{abstract}
Investigations were carried out in the farm soils of PAJANCOA \& RI, Karaikal in order to quantify the distribution of Phosphorus (P) in different pools using different statistical analysis. For this purpose, the surface soil samples of PAJANCOA \& RI farm, numbering 115 , were collected from individual fields. The soil samples were also analyzed through correlation analysis, linear multiple regression analysis and path analysis in order to quantify the interrelationship between the $\mathrm{P}$ fractions and extractants of $\mathrm{P}$. While correlating the $\mathrm{P}$ extracted by different extractants with that of the $\mathrm{P}$ fractions, it was noticed that the Olsen-P was positively related to HCl-P and Triacid-P, whereas the Bray-P was more closely related to the $\mathrm{NaCl}-\mathrm{P}$ fraction. It was estimated by multiple regression analysis that 33.2 per cent of the Olsen-P, 33.2 per cent of the Bray I-P and 35.9 per cent of the Bray II-P could be significantly predicted by the different $\mathrm{P}$ fractions. Attempts made to isolate the direct and indirect effects of the different $\mathrm{P}$ fractions on the $\mathrm{P}$ extracted by different reagents had shown that there was a moderate to low level of contribution by HCl-P and NaCl-P respectively towards the Olsen-P and a high level of negative contribution by $\mathrm{NaOH}-\mathrm{P}$. While the Bray I-P had a positive, direct and high level of contribution by the NaCl-P, the Bray II-P had a high level of direct and positive contribution from the NaCl-P.
\end{abstract}

\section{Introduction}

Phosphorus is the second most major element among the 17 essential elements for crop growth. Indian soils have poor $\mathrm{P}$ content. Primary $\mathrm{P}$ minerals including apatites, strengite and variscite are stable, and release of available $\mathrm{P}$ from these minerals by weathering is too slow to meet the crop demand and relatively efficient for crop growth in acidic soils. Secondary minerals including calcium, iron and aluminium phosphates vary in dissolution rates, depending on the size of mineral particles and soil pH (Pierzynski et al., 2005). One unique characteristics of $\mathrm{P}$ is its low availability due to slow diffusion and high fixation in soils. Phosphorus is highly mobile in plants and 
when the phosphorus is deficient, it may be translocated from old plant tissues to young actively growing areas.

The $\mathrm{P}$ status of neutral and alkali soils is expressed in terms of Olsen-P whereas, acid soils is expressed in terms of Bray I-P and Bray II-P which refers to the available soil $\mathrm{P}$ (Subba et al., 2015). In neutral to alkaline soils, $\mathrm{P}$ ions will precipitate as calcium phosphorus: dicalcium or octacalcium phosphates, hydroxyl apatite and eventually least soluble apatites and decreases $P$ availability. In acidic soils, the inorganic soil $\mathrm{P}$ precipitates as $\mathrm{Fe}$ and $\mathrm{Al}$ oxide and clay minerals, which are essentially insoluble under aerobic or upland conditions.

The scientific background of these phenomena and practical consequences for soil test interpretation and fertilizer application are subject to $\mathrm{P}$ dynamics in the soil. Therefore in order to understand the dynamic nature of the $\mathrm{P}$, various extractants can be used for extracting the different forms of $\mathrm{P}$ in soils. The Hedley et al., (1994) method of fractionation has been widely used to characterize soil $\mathrm{P}$ availability. It was reported that there was a decline in $\mathrm{NaOH}-\mathrm{P}$ with plant $\mathrm{P}$ removal. The $\mathrm{HCl}-\mathrm{P}$ and residual $\mathrm{P}$ in the slightly weathered soils declined under cropping. The NaOH-P was the dominant $\mathrm{P}$ fraction in the highly weathered soils and declined in response to plant $\mathrm{P}$ removal. NaOH-P and $\mathrm{NaHCO}_{3}-\mathrm{P}$ are readily available to plant, whereas the $\mathrm{HCl}-\mathrm{P}$ is unavailable to plants (Guo et al., 2000).

However, it was realized in the recent time from the soil analytical data and as well from the yield particulars, that there is a vast variation and erratic response to applied $\mathrm{P}$ in various fields of PAJANCOA \& RI farm. It was also noticed that in some fields there is serious decline in available $\mathrm{P}$ levels and some fields have very high values of available $P$.
This necessitated an investigation on the dynamics of soil $P$ in the farm soils of PAJANCOA \& RI with the objectives as to study the fractions of soil $\mathrm{P}$ in the soils and to select a suitable extractant for the soils of this farm.

In order to quantify the interrelationship between the $\mathrm{P}$ fractions and $\mathrm{P}$ extracted by different reagents, the soil samples were also analyzed through correlation analysis, linear multiple regression analysis and path analysis. The correlation and linear multiple regression is usually applied to explore the relationships between the fractions and extractants of P. Path analysis was developed around 1918 by Sewall Wright. It was usually used to decompose correlations into direct and indirect effects for interpretation.

\section{Materials and Methods}

\section{Description of study area}

The Pandit Jawaharlal Nehru college of Agriculture and Research Institute is about 9 $\mathrm{km}$ northwest to Karaikal and lies between $10^{\circ}$ $49^{\prime}$ and $11^{\circ} 01^{\prime} \mathrm{N}$ latitude and between $78^{\circ} 43^{\prime}$ and $79^{\circ} 52^{\prime} \mathrm{E}$ longitude. The study area is situated $4 \mathrm{~m}$ above mean sea level (MSL) having the maximum and minimum of $31.95^{\circ}$ $\mathrm{C}$ and $25.52^{\circ} \mathrm{C}$ temperatures. Karaikal comes under the eleventh Agro climatic zone of India and it is classified as PC 2 - coastal deltaic alluvial plain zone. Karaikal enjoys a tropical climate and receives an annual average rainfall of $1437.17 \mathrm{~mm}$ in 55.83 rainy days in North East Monsoon. The college farm is located in the tail end of Cauvery delta zone, $12 \mathrm{~km}$ away from the Bay of Bengal seacoast. The total area of farm in which the institute located is 225 acres. Currently, the eastern farm and western farm is divided into six blocks (A, B, C, D, E and F), occupies an area of 73.95 acres and 25.25 acres respectively. Totally an area of 99.20 acre is 
now taken as the study area in the present investigation. The detailed soil survey of PAJANCOA \& RI farm had indicated the presence of three soil series viz., (i) Sorakudy series. (ii) Thirunallar series (iii) Kottucherry series.

\section{Collection of surface soil sample}

The surface soil samples (15 cm depth) were collected during summer from PAJANCOA fields, when the fields were fallow, by adopting the standard procedures of soil sample collection from which, a composite soil sample of about one $\mathrm{kg}$ was collected by quartering technique. The collected soil samples were air dried, gently malleted and sieved through $2 \mathrm{~mm}$ sieve and preserved in polythene bags with proper labelling for further analysis.

\section{Soil analytical methods}

The surface soil samples were analyzed for available $\mathrm{P}$ by different extractants using 0.5 $\mathrm{M} \mathrm{NaHCO}_{3}$ of $\mathrm{pH} 8.5$ (Olsen et al., 1954) for Olsen-P, whereas Bray I and Bray II-P by $0.03 \mathrm{~N} \mathrm{NH}_{4} \mathrm{~F}$ plus $0.025 \mathrm{~N} \mathrm{HCl}$ and $0.03 \mathrm{~N}$ $\mathrm{NH}_{4} \mathrm{~F}$ plus $0.1 \mathrm{~N} \mathrm{HCl}$ (Bray and Kurtz, 1945), respectively in spectrophotometer. The different $\mathrm{P}$ fractions in soil were determined following a modified $\mathrm{P}$ fraction technique, as described by Bolan and Hedley (1989). The procedure is detailed here under:

One gram soil was pre-treated with $40 \mathrm{ml}$ of $0.5 \mathrm{M} \mathrm{NaCl}$ buffered with $0.5 \mathrm{M}$ triethanolamine (TEA) and shaken for 30 minutes in a $50 \mathrm{ml}$ centrifuge tube. This pretreated soil was included to remove both the solution $\mathrm{P}$ and exchangeable calcium, which otherwise may form $\mathrm{Ca}(\mathrm{OH})_{2}$ and $\mathrm{CaCO}_{3}$ during extraction with $1 \mathrm{M} \mathrm{NaOH}$ and readsorb or co-precipitate with some of the dissolved P. After centrifuging at $8000 \mathrm{rpm}$ for 10 minutes, the supernatant solution was filtered and analyzed for solution $\mathrm{P}$ following Murphy and Riley (1962) method.

The soil residue were subsequently shaken end-over-end with $1 \mathrm{M} \mathrm{NaOH}$ (at 1:40 soil: solution ratio) for 16 hours. After centrifuging and filtering, the solution was analyzed for $\mathrm{P}$ which include both solution and adsorbed $\mathrm{P}$.

To the residue in the tube $40 \mathrm{ml}$ of $1 \mathrm{M} \mathrm{HCl}$ was added and shaken for further 16 hours and then centrifuged and filtered. The $\mathrm{P}$ was determined in the solution as acid soluble or apatite-P. The soil residue was then transferred to a $100 \mathrm{ml}$ conical flask and digested using $10 \mathrm{ml}$ of triacid at $260^{\circ} \mathrm{C}$ for 45 minutes and the total $\mathrm{P}$ was determined as residual $\mathrm{P}$.

\section{Statistical analysis}

The analytical data obtained in the study were subjected to statistical scrutiny, simple correlation and multiple regression analysis following the procedures outlined by Gomez and Gomez (1976), to derive a valid conclusion. Path analysis was made to partition and quantify the direct and indirect effects of various fractions of soil $\mathrm{P}$ and $\mathrm{P}$ extracted by different extractants (Lenka and Misra, 1973).

\section{Results and Discussion}

\section{Phosphorus extracted by different reagents}

The quantity of $\mathrm{P}$ that can be extracted by different extractants viz., Olsen-P, Bray I-P, Bray II-P is presented in Table 1. The results had indicated that the Olsen extractant recorded the $\mathrm{P}$ which ranged between 4.09 to $415.15 \mathrm{~kg} \mathrm{ha}^{-1}$ with a mean value of 115.12 $\mathrm{kg} \mathrm{ha}^{-1}$, when all the fields were subjected to descriptive statistics. With respect to the eastern farm soils the minimum Olsen-P content was $10.90 \mathrm{~kg} \mathrm{ha}^{-1}$ and the maximum 
was $414.15 \mathrm{~kg} \mathrm{ha}^{-1}$ and the mean value was $132.60 \mathrm{~kg} \mathrm{ha}^{-1}$. In the case of the soils of the western farm, the minimum and the maximum values of $\mathrm{P}$ as extracted by Olsen reagent was 4.09 and $185.26 \mathrm{~kg} \mathrm{ha}^{-1}$ respectively and the mean value was $75.17 \mathrm{~kg} \mathrm{ha}^{-1}$.

Alternatively, the P extracted by the Bray I-P reagent was found to range between 46.88 to $774.77 \mathrm{~kg} \mathrm{ha}^{-1}$ with a mean value of 194.24 $\mathrm{kg} \mathrm{ha}^{-1}$ on an overall farm level. As regards the soils of eastern farm the minimum and maximum values of $\mathrm{P}$ as extracted by Bray I$P$ reagent was $46.88 \mathrm{~kg} \mathrm{ha}^{-1}$ and $774.77 \mathrm{~kg}$ $\mathrm{ha}^{-1}$ with an average value of $201.58 \mathrm{~kg} \mathrm{ha}^{-1}$. In the case of the soils of western farm the lowest content of P extracted by the Bray II reagent was $20.39 \mathrm{~kg} \mathrm{ha}^{-1}$ and the highest value was $374.76 \mathrm{~kg} \mathrm{ha}^{-1}$. On an average an amount of $98.66 \mathrm{~kg} \mathrm{ha}^{-1}$ was registered in the western farm soil.

\section{Fractions of $\mathbf{P}$}

The results are presented in Table 2 which had shown that the NaCl-P content of the surface soils of the farm ranged from 8.28 to $320.95 \mathrm{mg} \mathrm{kg}^{-1}$ with a mean value of 104.75 $\mathrm{mg} \mathrm{kg}^{-1}$. In the case of the eastern farm soils the minimum and maximum NaCl-P was 8.28 and $320.95 \mathrm{mg} \mathrm{kg}^{-1}$ with a mean value of $99.21 \mathrm{mg} \mathrm{kg}^{-1}$. With respect to the western farm the values of $\mathrm{NaCl}-\mathrm{P}$ was found to range between 8.28 to $270.48 \mathrm{mg} \mathrm{kg}$ with an average NaCl-P content of $114.28 \mathrm{mg} \mathrm{kg}^{-1}$.

The $\mathrm{P}$ extracted by $\mathrm{NaOH}$ was found to be ranging between 40.87 to $611.42 \mathrm{mg} \mathrm{kg}^{-1}$ in the overall farm, between the same values in the eastern farm and in the western farm the minimum $\mathrm{NaOH}-\mathrm{P}$ was 287.73 and the maximum was $549.77 \mathrm{mg} \mathrm{kg}^{-1}$ with an average value of $389.95 \mathrm{mg} \mathrm{kg}^{-1}$.

With respect to the $\mathrm{HCl}-\mathrm{P}$ content of the entire farm soils, the minimum value was
$103.85 \mathrm{mg} \mathrm{kg}^{-1}$ and the maximum value was $623.09 \mathrm{mg} \mathrm{kg}^{-1}$ with a mean value of 383.38 $\mathrm{mg} \mathrm{kg}$. In the case of the soils of eastern farm the $\mathrm{HCl}-\mathrm{P}$ was found to vary between $103.85 \mathrm{mg} \mathrm{kg}^{-1}$ to $610.17 \mathrm{mg} \mathrm{kg}^{-1}$ with an average value of $407.85 \mathrm{mg} \mathrm{kg}^{-1}$ of $\mathrm{HCl}-\mathrm{P}$. The minimum and maximum value of $\mathrm{HCl}-\mathrm{P}$ was $103.85 \mathrm{mg} \mathrm{kg}^{-1}$ and $623.09 \mathrm{mg} \mathrm{kg}^{-1}$ in the soils of the western farm. The average HCl-P content of the western farm soil was 327.58 $\mathrm{mg} \mathrm{kg}^{-1}$.

The Triacid-P content of the farm soils of PAJANCOA \& RI was found to range from nil to $155.48 \mathrm{mg} \mathrm{kg}^{-1}$ with an average value of $38.50 \mathrm{mg} \mathrm{kg}^{-1}$. While the eastern farm soil had also registered the same minimum and maximum values as quoted for the farm, the western farm soils was found to possess from nil to $45.77 \mathrm{mg} \mathrm{kg}^{-1}$ of Triacid-P with an average value of $21.09 \mathrm{mg} \mathrm{kg}^{-1}$.

The simple correlation studies had indicated that there existed a positive and significant relationship between the Olsen-P and that of $\mathrm{HCl}-\mathrm{P}$ and Triacid-P but negative relationship with NaOH-P. On the contrary, the Bray I-P and Bray II-P had recorded a highly significant and a positive relationship with the $\mathrm{NaCl}-\mathrm{P} \quad\left(\mathrm{r}=0.572^{* *}\right.$ and 0.575**, respectively) (Table 3). However, it was noticed that the Olsen-P registered significant and positive relationship with the $\mathrm{P}$ extracted by Bray II reagent and the Bray I-P was very significantly correlated with Bray II-P. Interestingly, the Bray II-P had significant and positive correlation with the $\mathrm{P}$ extracted by the other two reagents (Table 3 ).

In order to quantify the contribution of the different fractions of $\mathrm{P}$ towards the $\mathrm{P}$ extracted by different reagents, multiple linear relationship was worked out between the above two parameters and presented in Table 4. It was clearly brought out that 33.2 per cent of the variation in the Olsen-P and the Bray I- 
$P$ and 35.9 per cent of the variation in the Bray II-P could be significantly explained by the different fractions of P. Further scrutiny of the regression equation had shown that all the fractions of $\mathrm{P}$ except the Triacid-P had significant contribution to Olsen-P. On the other hand in the case of the Bray I and Bray II-P the contribution of $\mathrm{NaCl}$ alone was significant as revealed by the statistical tools.

The results of the path analysis had indicated that among the different fractions of $\mathrm{P}$, the $\mathrm{HCl}-\mathrm{P}$ had moderate and positive contribution and that of $\mathrm{NaCl}-\mathrm{P}$, a low and positive contribution towards the Olsen-P (Table 5). However, the NaOH-P had a high level of contribution with negative influence on the
Olsen-P. It was also noticed that the NaOH-P had a moderate to low level of contribution towards the Olsen-P via HCl-P and Triacid-P respectively. Among the different fractions of $\mathrm{P}$, the $\mathrm{NaCl}-\mathrm{P}$ alone had contributed directly to the $\mathrm{P}$ extracted by the Bray I reagent (Table $6)$.

The indirect effect was not noticed with respect to any of the fractions. With respect to the $\mathrm{P}$ extracted by the Bray II reagent, the $\mathrm{NaCl}-\mathrm{P}$ had a high level of positive and direct contribution, whereas the NaOH-P and Triacid-P had a negative and low level of contribution (Table 7). The NaOH-P had indirectly contributed to the Bray II-P through $\mathrm{HCl}-\mathrm{P}$, though the contribution was low.

Table.1 The available $\mathrm{P}$ of the surface soil samples of PAJANCOA \& RI farm using different extractants $\left(\mathrm{kg} \mathrm{ha}^{-1}\right)$

\begin{tabular}{|c|c|c|c|}
\hline Descriptive statistics & Olsen-P & Bray I-P & Bray II-P \\
\hline \multicolumn{4}{|c|}{ Overall Farm Soil } \\
\hline Mean & 115.12 & 194.24 & 126.35 \\
\hline S.E & 6.85 & 12.28 & 10.29 \\
\hline S.D & 73.46 & 131.71 & 110.32 \\
\hline C.V (\%) & 63.81 & 67.81 & 87.31 \\
\hline Minimum & 4.09 & 46.88 & 7.65 \\
\hline Maximum & 415.15 & 774.77 & 605.48 \\
\hline \multicolumn{4}{|c|}{ Eastern Farm Soil } \\
\hline Mean & 132.60 & 201.58 & 138.46 \\
\hline S.E & 8.66 & 16.43 & 13.30 \\
\hline S.D & 77.42 & 146.96 & 118.93 \\
\hline C.V (\%) & 58.39 & 72.90 & 85.90 \\
\hline Minimum & 10.90 & 46.88 & 7.65 \\
\hline Maximum & 415.15 & 774.77 & 605.48 \\
\hline \multicolumn{4}{|c|}{ Western Farm Soil } \\
\hline Mean & 75.17 & 177.44 & 98.66 \\
\hline S.E & 7.18 & 14.71 & 13.94 \\
\hline S.D & 42.48 & 87.01 & 82.49 \\
\hline C.V (\%) & 56.51 & 49.04 & 83.61 \\
\hline Minimum & 4.09 & 85.87 & 20.39 \\
\hline Maximum & 185.26 & 387.08 & 374.76 \\
\hline
\end{tabular}


Table.2 The fractions of $\mathrm{P}$ of surface soil samples of PAJANCOA \& RI farm $\left(\mathrm{mg} \mathrm{kg}^{-1}\right)$

\begin{tabular}{|c|c|c|c|c|}
\hline Descriptive statistics & NaCl-P & NaOH-P & HCl-P & Triacid-P \\
\hline \multicolumn{5}{|c|}{ Overall Farm Soil } \\
\hline Mean & 104.75 & 268.24 & 383.38 & 38.50 \\
\hline S.E & 6.82 & 13.46 & 10.74 & 3.79 \\
\hline S.D & 72.86 & 143.73 & 114.66 & 40.47 \\
\hline C.V (\%) & 69.56 & 53.58 & 29.99 & 105.12 \\
\hline Minimum & 8.28 & 40.87 & 103.85 & 0.00 \\
\hline Maximum & 320.95 & 611.42 & 623.09 & 155.48 \\
\hline \multicolumn{5}{|c|}{ Eastern Farm Soil } \\
\hline Mean & 99.21 & 214.12 & 407.85 & 46.41 \\
\hline S.E & 8.04 & 15.46 & 12.13 & 5.14 \\
\hline S.D & 71.47 & 137.39 & 107.84 & 45.72 \\
\hline C.V (\%) & 72.03 & 64.17 & 26.44 & 98.50 \\
\hline Minimum & 8.28 & 40.87 & 103.85 & 0.00 \\
\hline Maximum & 320.95 & 611.42 & 610.17 & 155.48 \\
\hline \multicolumn{5}{|c|}{ Western Farm Soil } \\
\hline Mean & 114.28 & 389.95 & 327.58 & 21.09 \\
\hline S.E & 12.78 & 9.81 & 18.95 & 2.25 \\
\hline S.D & 74.50 & 57.19 & 110.52 & 13.14 \\
\hline C.V (\%) & 65.19 & 14.67 & 33.74 & 62.30 \\
\hline Minimum & 8.28 & 287.73 & 103.85 & 0.00 \\
\hline Maximum & 270.48 & 549.77 & 623.09 & 45.77 \\
\hline
\end{tabular}

Table.3 Results of the simple correlation studies between the fractions of $\mathrm{P}$ and $\mathrm{P}$ extracted by different extractants of the surface soils of PAJANCOA \& RI farm $(n=115)$

\begin{tabular}{|c|c|c|c|c|}
\hline Sl. No. & Particulars & Olsen-P & Bray I-P & Bray II-P \\
\hline 1. & NaCl-P & $0.173^{\mathrm{NS}}$ & $0.572^{* *}$ & $0.575^{* *}$ \\
\hline 2. & $\mathrm{NaOH}-\mathrm{P}$ & $-0.513^{* *}$ & $0.029^{\mathrm{NS}}$ & $-0.101^{\mathrm{NS}}$ \\
\hline 3. & $\mathrm{HCl}-\mathrm{P}$ & $0.478^{* *}$ & $0.018^{\mathrm{NS}}$ & $0.084^{\mathrm{NS}}$ \\
\hline 4. & Triacid-P & $0.253^{* *}$ & $0.008^{\mathrm{NS}}$ & $0.004^{\mathrm{NS}}$ \\
\hline
\end{tabular}

Table.4 Results of the linear multiple regression studies between the fractions of $\mathrm{P}$ and $\mathrm{P}$ extracted by different extractants of surface soil samples of PAJANCOA \& RI farm

\begin{tabular}{|c|c|c|c|c|}
\hline Sl. No. & $\begin{array}{c}\text { Dependent } \\
\text { variable (Y) }\end{array}$ & $\begin{array}{l}\text { Independent variable } \\
\qquad(\mathrm{X})\end{array}$ & $\begin{array}{l}\text { Equation } \\
(\hat{\mathbf{Y}})\end{array}$ & $\mathbf{R}^{2}$ \\
\hline 1. & Olsen-P & $\begin{array}{l}\mathrm{NaCl}-\mathrm{P}\left(\mathrm{x}_{1}\right) ; \mathrm{NaOH}-\mathrm{P}\left(\mathrm{x}_{2}\right) \\
\mathrm{HCl}-\mathrm{P}\left(\mathrm{x}_{3}\right) ; \text { Triacid-P }\left(\mathrm{x}_{4}\right)\end{array}$ & $\begin{array}{l}\mathrm{Y}=90.37+0.170\left(\mathrm{x}_{1}\right)^{*}-0.194\left(\mathrm{x}_{2}\right)^{* *}+ \\
0.163\left(\mathrm{x}_{3}\right)^{*}-0.099\left(\mathrm{x}_{4}\right)^{\mathrm{NS}}\end{array}$ & $0.332 * *$ \\
\hline 2. & Bray I-P & $\begin{array}{l}\mathrm{NaCl}-\mathrm{P}\left(\mathrm{x}_{1}\right) ; \mathrm{NaOH}-\mathrm{P}\left(\mathrm{x}_{2}\right) \\
\mathrm{HCl}-\mathrm{P}\left(\mathrm{x}_{3}\right) ; \text { Triacid-P }\left(\mathrm{x}_{4}\right)\end{array}$ & $\begin{array}{l}\mathrm{Y}=69.83+1.024\left(\mathrm{x}_{1}\right)^{* *}+0.020\left(\mathrm{x}_{2}\right)^{\mathrm{NS}}+ \\
0.050\left(\mathrm{x}_{3}\right)^{\mathrm{NS}}-0.224\left(\mathrm{x}_{4}\right)^{\mathrm{NS}}\end{array}$ & $0.332 * *$ \\
\hline 3. & Bray II-P & $\begin{array}{l}\mathrm{NaCl}-\mathrm{P}\left(\mathrm{x}_{1}\right) ; \mathrm{NaOH}-\mathrm{P}\left(\mathrm{x}_{2}\right) \\
\mathrm{HCl}-\mathrm{P}\left(\mathrm{x}_{3}\right) ; \text { Triacid-P }\left(\mathrm{x}_{4}\right)\end{array}$ & $\begin{array}{l}\mathrm{Y}=73.74+0.880\left(\mathrm{x}_{1}\right)^{* *}-0.126\left(\mathrm{x}_{2}\right)^{\mathrm{NS}}+ \\
0.026\left(\mathrm{x}_{3}\right)^{\mathrm{NS}}-0.433\left(\mathrm{x}_{4}\right)^{\mathrm{NS}}\end{array}$ & $0.359 * *$ \\
\hline
\end{tabular}


Table.5 Results of the Path analysis showing the direct and indirect effect of the fractions of P to the P extracted by the Olsen reagent in the surface soils of PAJANCOA \& RI

\begin{tabular}{|l|c|c|c|c|c|c|}
\hline \multirow{2}{*}{$\begin{array}{c}\text { Fractions of } \\
\text { P }\end{array}$} & Direct & \multicolumn{4}{|c|}{ Indirect effects } & Total of indirect \\
effects & NaCl-P & NaOH-P & HCl-P & Triacid-P & 0.026 \\
\hline NaCl-P & $0.173^{\mathrm{L}}$ & & $0.000^{\mathrm{N}}$ & $0.005^{\mathrm{N}}$ & $0.021^{\mathrm{N}}$ & 0.430 \\
\hline NaOH-P & $-0.380^{\mathrm{H}}$ & 0.000 & & $0.241^{\mathrm{M}}$ & $0.189^{\mathrm{L}}$ & -0.057 \\
\hline HCl-P & $0.254^{\mathrm{M}}$ & 0.007 & -0.161 & & $0.097^{\mathrm{N}}$ & -0.000 \\
\hline Triacid-P & $-0.055^{\mathrm{N}}$ & -0.007 & 0.028 & -0.021 & & 0.021 \\
\hline
\end{tabular}

Table.6 Results of the Path analysis showing the direct and indirect effect of the fractions of $\mathrm{P}$ to the P extracted by the Bray I reagent in the surface soils of PAJANCOA \& RI

\begin{tabular}{|c|c|c|c|c|c|c|}
\hline \multirow{2}{*}{$\begin{array}{c}\text { Fractions of } \\
\mathbf{P}\end{array}$} & \multirow{2}{*}{$\begin{array}{l}\text { Direct } \\
\text { effects }\end{array}$} & \multicolumn{4}{|c|}{ Indirect effects } & \multirow{2}{*}{$\begin{array}{c}\text { Total of indirect } \\
\text { effects }\end{array}$} \\
\hline & & $\mathrm{NaCl}-\mathrm{P}$ & $\mathrm{NaOH}-\mathrm{P}$ & HCl-P & Triacid-P & \\
\hline NaCl-P & $0.579^{\mathrm{H}}$ & & $0.000^{N}$ & $0.016^{N}$ & $0.072^{N}$ & 0.088 \\
\hline NaOH-P & $0.021^{\mathrm{N}}$ & 0.000 & & $-0.013^{N}$ & $-0.011^{N}$ & -0.024 \\
\hline HCl-P & $0.043^{\mathrm{N}}$ & 0.001 & -0.027 & & $0.016^{\mathrm{N}}$ & -0.010 \\
\hline Triacid-P & $-0.070^{\mathrm{N}}$ & -0.009 & 0.035 & -0.027 & & -0.001 \\
\hline
\end{tabular}

Table.7 Results of the Path analysis showing the direct and indirect effect of the fractions of $\mathrm{P}$ to the P extracted by the Bray II reagent in the surface soils of PAJANCOA \& RI

\begin{tabular}{|c|c|c|c|c|c|c|}
\hline \multirow{2}{*}{$\begin{array}{c}\text { Fractions of } \\
\mathbf{P}\end{array}$} & \multirow{2}{*}{$\begin{array}{l}\text { Direct } \\
\text { effects }\end{array}$} & \multicolumn{4}{|c|}{ Indirect effects } & \multirow{2}{*}{$\begin{array}{c}\text { Total of indirect } \\
\text { effects }\end{array}$} \\
\hline & & $\mathrm{NaCl}-\mathrm{P}$ & $\mathrm{NaOH}-\mathrm{P}$ & $\mathrm{HCl}-\mathrm{P}$ & Triacid-P & \\
\hline NaCl-P & $0.594^{\mathrm{H}}$ & & $0.000^{N}$ & $0.016^{\mathrm{N}}$ & $0.074^{\mathrm{N}}$ & 0.090 \\
\hline NaOH-P & $-0.166^{\mathrm{L}}$ & 0.000 & & $0.105^{\mathrm{L}}$ & $0.083^{N}$ & 0.188 \\
\hline HCl-P & $0.025^{\mathrm{N}}$ & 0.001 & -0.016 & & $0.010^{\mathrm{N}}$ & -0.006 \\
\hline Triacid-P & $-0.162^{L}$ & -0.020 & 0.081 & -0.062 & & -0.001 \\
\hline
\end{tabular}

$\mathrm{N}=$ Negligible; $\mathrm{L}=$ Low $\mathrm{M}=$ Moderate $; \mathrm{H}=$ High

Various methodologies involving different extractants are being test verified under differing soil environments and by growing crops of varying duration. The complexity in predicting the actual quantity of nutrient element to the growing plant is that the supply is made from various sources under the field conditions, the quantity of which is difficult to assess.

Attempts made to relate the $\mathrm{P}$ extracted by different reagents with that of the $\mathrm{P}$ fractions in this study. Among the different soil $\mathrm{P}$ fractions, the $\mathrm{NaCl}-\mathrm{P}$ represents the solution
$\mathrm{P}$, which is instantaneously available, the $\mathrm{NaOH}-\mathrm{P}$ indicates the adsorbed $\mathrm{P}$ on the exchange complex which can be made available by a simple ion exchange phenomena, the HCl-P designates the acid soluble $\mathrm{P}$ fraction, which is not soluble but made soluble by a simple dissolution mechanism and the Triacid-P represents the mineral $\mathrm{P}$ which can be released only upon weathering. In simple terms, the $\mathrm{NaCl}-\mathrm{P}$ is instantaneously available and can be extracted even by water to any reagent, the $\mathrm{NaOH}-\mathrm{P}$ can be made available provided there is an appropriate competing ion to desorb $\mathrm{P}$ from 
the exchange complex, which is proportional to the type of extractant used (Tembhare, 1973). Therefore, these two fractions are designated as labile-P and easily available for crop uptake. On the other hand, the HCl-P derives its $\mathrm{P}$ by dissolving the insoluble precipitates of $\mathrm{P}$ which might not happen immediately under field conditions, but nevertheless gets released slowly. The Triacid-P is said to be the Residual-P which is not even dissolved by a strong acid like $\mathrm{HCl}$ and therefore is said to be relatively unavailable. Under this context, it can be inferred that irrespective of the type of reagent used to extract $\mathrm{P}$ and designating that amount as available $\mathrm{P}$, it can be inferred that all reagents are extracting the $\mathrm{P}$ completely from the $\mathrm{NaCl}$ pool, maximum from the $\mathrm{NaOH}$ pool and moderate from the $\mathrm{HCl}$ pool and none or less from the Triacid pool. In other words the quantity of $\mathrm{P}$ extracted by a reagent depends on the amount of $P$ that could be extracted from the adsorbed and acid soluble fraction of soil.

The present investigation had attempted to correlate the fractions of $\mathrm{P}$ with the $\mathrm{P}$ extracted by different reagents which brought out certain salient conclusions. For instance, the Olsen-P was not related to $\mathrm{NaCl}-\mathrm{P}$, negatively related to $\mathrm{NaOH}-\mathrm{P}$ and positively to HCl-P and Triacid-P. In the case of Bray I$\mathrm{P}$ and Bray II-P it was closely correlated with NaCl-P. The above information had brought out the fact that the Olsen-P values cannot be modified just because there are variations in the solution $\mathrm{P}$, but however derives its $\mathrm{P}$ from the adsorbed pool of the soil exchange complex thereby resulting in reduction of $\mathrm{NaOH}-\mathrm{P}$. A positive correlation of Olsen-P with $\mathrm{HCl}-\mathrm{P}$ and Triacid-P indicates that the $\mathrm{NaCl}-\mathrm{P}$ is either precipitated or the Olsen-P is independent of the insoluble $\mathrm{P}$ fraction. However, as far as Bray I and Bray II-P are considered there is a good relationship with the NaCl-P. Interestingly, the multiple regression analysis had clarified this contradiction between the Olsen-P and the Bray-P, wherein there were significant variations in Olsen-P due to $\mathrm{NaCl}, \mathrm{NaOH}$ and $\mathrm{HCl}-\mathrm{P}$, whereas it was only the NaCl-P which accounted the Bray I and Bray II-P (Abarna, 2012). The path analysis had yet again confirmed that the Olsen-P had a positive and direct contribution from NaCl-P and $\mathrm{HCl}-\mathrm{P}$ and a negative contribution from NaOH-P. In the case of Bray I-P and Bray II-P the direct contribution was positive and high with respect to $\mathrm{NaCl}-\mathrm{P}$.

\section{Acknowledgement}

The authors would like to acknowledge the Dean of College of Pandit Jawaharlal Nehru College of Agriculture and Research Institute and Head of Department Soil Science and Agricultural Chemistry, Karaikal, Puducherry for providing facilities for the successful completion of the work.

\section{References}

Abarna, G. 2012. Investigations on the phosphorus dissolution pattern of mussoorie rock phosphate and its impact on growth and yield of rice (Oryza sativa L.). M.Sc. (Ag.) Thesis. Tamil Nadu Agricultural University, Coimbatore. Tamil Nadu.

Bolan, N.S. and Hedley, M.J. 1989. Dissolution of phosphate rocks in soil: Evaluation of extraction methods for the measurement of phosphate dissolution. Fert. Res. 19: 65-75.

Bray, R.H and Kurtz, L.T. 1945. Determining total, organic and available forms of phosphorus in soils. Soil Sci. 59: 39-45.

Gomez, A.A. and Gomez. R.A. 1976. Statistical procedure for agricultural research with emphasis on rice. IARI. Los Banos, Manila, Philippines. Pp: 294. 
Guo, F., R.S. Yost, N.V. Hue, C.I. Evensen and Silva, J.A. 2000. Changes in phosphorus fractions in soils under intensive plant growth. Soil Sci. Soc. Am. J. 64:1681-1689.

Hedley, M.J., G.J.D. Kirk and Santos, M.B. 1994. Phosphorus efficiency and the forms of soil phosphorus utilized by upland rice cultivars. Plant Soil. 158: 53-62.

Lenka, D. and Misra. H. 1973. Path coefficient analysis of yield in rice varieties. Indian J. Agric. Sci. 43: 378379.

Olsen, S.R., C.V. Cole, F.S. Watanable and Dean, A.L.. 1954. Estimation of available phosphorus in soil by extraction with sodium bicarbonate.
USDA Circ. Pp: 939.

Pierzynski, G.M., R.W. McDowell and Sims, J. T. 2005. Chemistry, cycling, and potential moment of inorganic phosphorus in soils. In: Phosphorus: Agriculture and the Environment (Eds.) J.T Sims and A.N. Sharpley. Soil Sci. Soc. Am. Madison, WI, Pp 53-86.

Subba, R.A., S. Srivastava and Ganeshmurty, A.N. 2015. Phosphorus supply may dictate food security prospects in India. Curr. Sci. 108: 1253-1261.

Tembhare, B. 1973. Available and inorganic forms of phosphorus in selected Alfisols and Mollisols. Ph.D. (Ag.) Thesis. Iowa State University, Ames. Iowa.

\section{How to cite this article:}

Ashna Susan Joseph, A. Baskar, U. Bagavathi Ammal and Chellamuthu, V. 2020. Comparison between the Fractions and Extractants of Phosphorus of PAJANCOA and RI Farm using Different Statistical Analysis. Int.J.Curr.Microbiol.App.Sci. 9(09): 2953-2961. doi: https://doi.org/10.20546/ijcmas.2020.909.364 